\title{
William Henry Fry's Leonora: The Italian Connection
}

\author{
Francesco Izzo \\ University of Southampton
}

On 7 June 1845, the New York Herald published a letter by an 'occasional correspondent' from Philadelphia concerning William Henry Fry's first grand opera, Leonora, which premiered three days before at the Chestnut Street Theatre. The letter contained the following remark:

All were delighted with the music, it was so much like an old acquaintance in a new coat; indeed some of 'the cognoscenti' said that it was a warm 'hash' of Bellini, with a cold shoulder of 'Rossini,' and a handful of 'Auber' salt - whilst others congratulated Mr. Fry upon his opera being so much like Norma .... .'

Since that time, there has been a widespread consensus about the derivation of Leonora from Italian and French models. In 1890, Frédéric Louis Ritter claimed that in Fry's operas 'the cantilena [is] according to Italian models; the ensemble, orchestration, and dramatic arrangement, according to French tradition', ${ }^{2}$ while in 1904, Louis C. Elson pointed to another model, that of the English (but Italianate) composer Michael William Balfe ('[t]he numbers of this opera are rather weak copies of the styles of Balfe and Donizetti, but are melodious and pleasing'). ${ }^{3}$ In 1927, Edward Ellsworth Hipsher did not go beyond a strikingly (and likely deliberately) literal paraphrase of Ritter's words (' $\mathrm{t}]$ here was cantilena after the Italian model; but the dramatic arrangement, orchestration and ensemble followed French traditions'), adding that 'the work was weakened by an overplus of recitatives which, unfortunately, had not the suavity nor the spontaneously and expressively dramatic fitness which characterize the better Italian art of this nature' ${ }^{4}$ When Leonora was revived for a New York concert performance in 1929, critics of the most authoritative newspapers commented - this time mostly in a negative tone - on Fry's imitation of Italian models, especially those of Bellini's Norma. ${ }^{5}$

More recent criticism has followed in a similar vein. William Treat Upton, the author of the only substantial study on Fry (1954), indicated that Norma

1 Cited in Vera Brodsky Lawrence, Strong on Music: The New York Music Scene in the Days of George Templeton Strong, 1836-1875, vol. 1, Resonances 1836-1850 (New York and Oxford: Oxford University Press, 1988): 630.

2 Frédéric Louis Ritter, Music in America (New York: Charles Schribner's Sons, 1890): 320.

3 Louis C. Elson, The History of American Music (London: MacMillan \& Co., 1904): 110.

4 Edward Ellsworth Hipsher, American Opera and its Composers (Philadelphia, PA: Theodore Presser, 1927): 208.

5 See John Tasker Howard, Our American Music (New York: Thomas Y. Crowell Company, 1939): 247.

Nineteenth-Century Music Review, 6/1 (2009): 7-25. Copyright @ $\odot$ Ashgate Publishing Ltd. 
was the closest model to Leonora, although he stated that 'while there is a close formal relation between the two, Leonora is no mere copy'. ${ }^{6}$ In 1969 , H. Wiley Hitchcock wrote that Leonora's 'fashionably Romantic plot and Belliniesque music must have made it seem very up-to-date' ${ }^{7}$ And in 1983, Charles Hamm made the drastic claim that 'There is no detail of the music of Leonora ... that does not derive directly from Rossini, Bellini, and Donizetti', ${ }^{8}$ while John Graziano in the Grove Dictionary of Opera (1992) states that at the time of Leonora Fry was 'a composer primarily influenced by the melodic style of Bellini and the Italian school ... . .9

In spite of (or perhaps because of) such widespread agreement concerning the dependence of Leonora on European (and especially Italian) models, scholars still lack a study of the opera that examines its formal procedures, melodic style, vocal writing and accompaniment techniques against the backdrop of early- and midnineteenth-century European opera, particularly in the light of those composers and works known to William Henry Fry and to opera-goers in Philadelphia. To that end, I will explore the Italian influences in Leonora through a close study of its historical background, libretto and music.

\section{William Henry Fry and the Beginnings of European Opera in Philadelphia}

The first visit of the French opera company of New Orleans in 1827 marked the beginning of a glorious operatic tradition in Philadelphia. The same company became a regular presence on the city stage for several years, and introduced French works such as Boïeldieu's La Dame blanche and Jean de Paris, Auber's La Muette de Portici and Fra Diavolo, operas by Grétry, Dalayrac and Méhul, as well as Weber's Der Freischütz (given in French as Robin de Bois). The first Italian troupe to visit Philadelphia was the Montresor Company in 1833, with a repertory that included Mercadante's Elisa e Claudio, Bellini's Il pirata, and Rossini's L'italiana in Algeri, La Cenerentola, Otello and Mosé in Egitto. ${ }^{10}$ These were followed in 1834 by performances by the Rivafinoli Opera Company of Rossini's Il barbiere di Siviglia, La Cenerentola, La donna del lago, La gazza ladra and Matilde di Shabran, Cimarosa's Il matrimonio segreto, and Pacini's Gli arabi nelle Gallie. ${ }^{11}$ The young Fry, who had returned to Philadelphia from his studies at Mount St Mary's College in Maryland in 1830, and had become a pupil of Leopold Méignen, attended

\footnotetext{
6 William Treat Upton, William Henry Fry: American Journalist and Composer-Critic (New York: Crowell, 1954): 184.

7 H. Wiley Hitchcock, Music in the United States: A Historical Introduction (Englewood Cliffs, NJ: Prentice-Hall, 1969): 88.

8 Charles Hamm, Music in the New World (New York and London: Norton, 1983): 203.

9 John Graziano, 'Fry, William Henry', in New Grove Dictionary of Opera, 4 vols, ed. Stanley Sadie (London: Macmillan, 1992), vol. 2: 313.

10 See John Curtis, 'A Hundred Years of Grand Opera in Philadelphia' (unpublished typescript), 7 vols (US-PHhs, 1920), vol. 1: 163-73. The Montresor Company made its debut in New York in 1832, and was ostensibly the first to produce an entire season of Italian opera in the United States. See Katherine K. Preston, Opera on the Road: Traveling Opera Troupes in the United States, 1825-60 (Urbana and Chicago: University of Illinois Press, 1993): 107-8 and passim.

11 Curtis, 'A Hundred Years of Grand Opera in Philadelphia', vol. 1: 191-7. On the company led by Vincenzo Rivafinoli and its activities in Philadelphia and elsewhere, see Preston, Opera on the Road, 109-11.
} 
most of these productions and reviewed several of them, rapidly developing a substantial knowledge of the contemporary European operatic canon. ${ }^{12}$

Following the short-lived enterprises of Montresor and Rivafinoli, no Italian company visited Philadelphia between 1834 and $1843 .{ }^{13}$ The operas of contemporary Italian masters continued to be heard, however, though translated into English and heavily abridged. These English-language performances of Italian operas were typically brought to Philadelphia and other North American cities by English opera troupes, and were presumably very similar (if not identical) to the arrangements prepared by Henry Rowley Bishop, Michael Rophino Lacy and others that were presented frequently in London. Such arrangements typically involved not only the translation of the original Italian poetry, but also the introduction of spoken dialogue in place of recitatives, and numerous cuts, replacements and interpolations throughout the score. ${ }^{14}$ In this form, Fry heard Bellini's La sonnambula, as well as several of the works previously performed by the Montresor and Rivafinoli companies. The young composer, who by the mid1830s had begun writing music criticism for the National Gazette (the authoritative Philadelphia-based journal published by Fry's father, also named William), had developed a strong predilection for Italian opera composers and singers, and his recollections of the Italian performances of 1833-34 reveal a special admiration for Rossini and Bellini. In November 1837, reacting to performances of Bellini's La sonnambula and Rossini's La Cenerentola by an English company, he claimed that 'the vulgar prejudices which exist in our country against Italian music are based upon erroneous impressions,' and he stated that the public had 'discovered in Bellini's Sonnambula, even though a miserable translation and a very indifferent production on our theatre, that Italian music can be simple, passionate, and effective, and that its melodies are unequalled in commanding popular applause and affection'. ${ }^{15}$ His negative remarks on the translations were paired with comments on 'the bad singing of Mr. Sinclair, [who] with his ridiculous roulades hitched to Scotch ditties' added unnecessary and inappropriate ornaments to Bellini's music. ${ }^{16}$ By contrast, the 1833 performance of Il pirata by Montresor had made a lasting positive impression on Fry, and provided a good basis for comparison: 'Montressor [sic], a good Italian singer though past his prime, in

12 To date the most detailed discussion of operatic life in nineteenth-century Philadelphia remains John Curtis's monumental typescript of 1920, 'A Hundred Years of Grand Opera in Philadelphia'. See also W.G. Armstrong, A Record of the Opera in Philadelphia (Philadelphia: Porter \& Coates, 1884) and Upton, William Henry Fry, 14-16, which attests to the young composer's enthusiasm for opera and cites many of his reviews.

13 The Italian Opera Company of Havana visited Philadelphia in July 1843, presenting a short season that included the Philadelphia premieres of Donizetti's Lucia di Lammermoor and Belisario and Bellini's I puritani, as well as the first performance of Norma in Italian. See Curtis, 'A Hundred Years of Grand Opera', vol. 1, 305-07.

14 Discussions of adaptations of Italian operas for the London stage include Nadia Carnevale, '“... That's the Barber!": Henry Rowley Bishop e l'adattamento del Barbiere rossiniano', in Ottocento e oltre: Scritti in Onore di Raoul Meloncelli, ed. Francesco Izzo and Johannes Streicher (Rome: Editoriale Pantheon, 1993): 99-113, and Stuart W. Rogers, 'Cenerentola a Londra', Bollettino del Centro Rossiniano di Studi 37 (1997): 51-67. A pianovocal score of the adaptation of La Cenerentola is found in John Graziano, ed., Cinderella (1831): Adapted by M. Rophino Lacy from Gioachino Rossini's'La Cenerentola, NineteenthCentury American Musical Theater 3 (New York: Garland, 1994).

15 Cited in Upton, William Henry Fry, 37.

16 Scottish tenor John Sinclair toured extensively in the United States between 1831 and 1842. See Preston, Opera on the Road, 25. 
his impersonation of the Pirate, never indulged in extraneous ornament, but confined himself rigidly to Bellini's passionate strains ... . ${ }^{\prime 17}$

It is remarkable that in this review the young composer and critic, whose short compositions had begun to appear on concert programmes in Philadelphia, ventured into such treacherous ground as comparing performances by different companies presented several years apart, and it is inevitable to wonder to what extent we should trust Fry's memory and good faith, not to mention the sources at his disposal to support the claim that Montresor had 'confined himself' to Bellini's original music, rather than adding 'unnecessary and inappropriate ornaments'. But the statement is to be taken seriously if viewed as the artistic creed of a young musician who was about to become directly involved with the local operatic scene well beyond the columns of the National Gazette.

\section{The American Premiere of Norma}

As a composer, William Henry Fry had been active since the mid-1830s, producing among other works several orchestral overtures, performed in concert in Philadelphia. In 1838, Fry began work on Aurelia the Vestal, an opera to a libretto by his brother Joseph, in turn apparently based on an Italian text entitled Cristiani e Pagani. The composition of Aurelia the Vestal was completed in July 1841, but it seems the opera never reached the stage. ${ }^{18}$ Its enticing Italian background and the ties between its classically inspired plot and various Italian operas (most notably, Bellini's Norma) again attest to Fry's fascination with contemporary Italian operatic culture.

During the composition of Aurelia the Vestal, Fry was primarily involved in a crucial moment for the reception of Italian opera in the United States - the American premiere of Vincenzo Bellini's Norma on 11 January 1841 at the Chestnut Street Theatre, Philadelphia. This was an affair entirely in the hands of the Fry family. Fry's brother, Joseph Reese Fry translated the original libretto by Felice Romani into English, while another brother, Edward, dealt with the managerial aspects of the production. William Henry himself supervised the musical preparation. ${ }^{19}$

No performance materials for the American premiere of Norma seem to have survived, nor was a complete piano-vocal score published in the United States at the time of this production. Several excerpts and arrangements appeared in print shortly after the premiere of the opera, however, all of them using Joseph Fry's translation. One of them, a piano-vocal score of Pollione's cavatina published by Gihon and Co., acknowledged Joseph Fry on the title page, emphasizing that his translation of Romani had been adapted to 'the original music' ${ }^{20}$ So did the printed libretto for this production of Norma, which showcased the names of

17 Upton, William Henry Fry, 37.

18 Aurelia the Vestal and its relation to Cristiani e Pagani is discussed in Upton, ibid., 23-5. See also Graziano, 'Fry, William Henry'.

19 Upton, William Henry Fry, $25 \mathrm{ff}$.

20 See Vincenzo Bellini, When Bound in Slumber's Golden Chain: The words, Translated from the Italian of Romani, and Adapted to the Original Music, by Jos. Reese Fry (Philadelphia, PA: G. Willig, 1841). 
Bellini and Romani prominently on the title page, suggesting again that the Frys were claiming the merit of having adhered to their texts as closely as possible. ${ }^{21}$

Joseph Fry's translation is indeed remarkably faithful in structure and content to Romani's original poetry, and all of the numbers appear in the same order as in the original score. There are some enticing discrepancies, however. The opera is divided into three acts instead of two (the original Act II is divided into two different acts), and the names of several characters are changed. More significantly, substantial differences in the syllable counts of several recitatives make one wonder whether these were actually sung to Bellini's music. For example, under Joseph Fry's pen the final portion of Norma's recitative (freely alternating, as customary, between 7- and 11-syllable lines) became a significantly longer passage:

In pagine di morte

Della superba Roma è scritto il nome;

Ella un giorno morrà; ma non per voi, Morrà pei vizi suoi,

Qual consunta morrà. L'ora aspettate, L'ora fatal, che compia il gran decreto.

Pace v'intimo, e il sacro vischio io mieto.
On death's eternal tablets is the name

Of proud and cruel Rome most darkly graven: There have I read her dire and certain doom. That doom ye cannot speed: the measure deep Of all her crimes o'erflowing, she ere long Must drain, and thus forever fall! Peace now Compatriots and our hallowed work attend!22

And in the famous ensuing aria, 'Casta diva', whose Italian poetry consists of two quatrains of ottonari, a fifth line was added, which, however, could be easily accommodated by reducing the number of textual repetitions in Bellini's setting. In Joseph Fry's translation, the lyrical sections are often introduced with titles recalling their musical or dramatic function, or with the name of the character involved printed in small caps and centered. 'Casta diva', for example, is entitled 'Prayer to the New Moon':

Prayer to the New Moon

Casta diva, che inargenti Queste sacre antiche piante A noi volgi il bel sembiante, Senza nube, e senza vel.

Tempra o diva, tempra ancora Tempra ancor lo zelo audace, Spargi in terra quella pace Che regnar tu fai nel ciel.
Virgin Goddess, beaming brightly Where the pale stars glimmer nightly, Smiling now in cloudless beauty Hallow thou our votive duty, Be propitious to our call! May thy placed light assuaging Calm these bosoms fiercely raging; May thy presence felt divinely Peace on earth diffuse benignly As in heaven it blesseth all! ${ }^{23}$

The Frys had every good reason to be satisfied with the outcome of their efforts. The premiere of Norma was one of the most successful operatic endeavours in the United States at that time, and attracted spectators from as far as New York and Boston. To maximize the impact of this event on the public, eight days after the first performance William Henry published a detailed review of Norma in

21 Norma: A Lyrical Tragedy in Three Acts: Translated from the Italian of Felice Romani, and Adapted to the Original Music of Bellini, by Jos. Reese Fry (Philadelphia: John H. Gihon \& Co., 1841). All quotations are from this libretto.

22 Ibid, 7-8.

23 Ibid, 8. 
the National Gazette. ${ }^{24}$ Given the involvement of the Frys in the production, it comes as no surprise that his criticism of the work and of its performance was unconditionally favourable. Conflict of interest notwithstanding, Fry discussed the dramatic and musical qualities of Norma with great acumen. He concluded with the following statement:

Considered in every department the opera of Norma as now performed is a dramatic and musical exhibition which merits the ardent support of everyone pretending to any sympathy with the progress of the Fine Arts.... Everyone who is familiar with the condition of the English opera in London must sustain us in the assertion that with all the music facilities at hand in that mighty metropolis, there never has been any realization of the works of a great composer, equal on the whole to the performance of Bellini's Norma at the Chestnut Street Theatre. ${ }^{25}$

It is indeed tempting to give only a benevolent smile at the naivety of this statement, especially coming from someone who had never visited London or any other 'mighty metropolis'. But these words need not be taken literally. Rather, they represent another crucial aspect of Fry's cultural manoeuvre: having provided the public with an opportunity to become better acquainted with Bellini's music, he now flattered them by putting forward a comparison between Philadelphia and London. Not only was Norma a great masterpiece, but its greatness was also projected on Philadelphians, who had had the honour of hosting such a fine production of the opera. Shortly following the production of Norma, a performance of Mozart's The Magic Flute in February 1841 gave Fry the opportunity to continue his campaign in favour of Italian opera, praising the Italian school ('the real vocal school') over the German, and remarking that '[s]ingers of German music in general lie under this disadvantage: the supremacy of the voice is hardly acknowledged in the score' ${ }^{26}$

In 1844, the Frys organized another production of an Italian opera translated into English: Anna Bolena by Felice Romani and Gaetano Donizetti. A French version of Anna Bolena had already circulated in several American cities, and its production in English did not stir the same enthusiasm as Norma. In this case the printed libretto mentions neither Felice Romani nor Joseph Fry, but only 'Signor Donizetti' and, as the title page suggests, collects only the lyrical sections of the opera. ${ }^{27}$ Nonetheless, the prosody of the translation of the poetry suggest that the original music was employed. By this time the National Gazette had ceased publication, and there is no indication that Fry reviewed the performance.

The two productions organized by the Frys are of pivotal importance. Viewed in preparation for the premiere of Leonora, which Fry had begun composing as early as 1841, the significance of Norma and Anna Bolena is twofold: on one hand, they served the purpose of fostering the public's knowledge of, and predilection for, the contemporary Italian school; on the other, they provided the Fry brothers with a unique opportunity to deepen their acquaintance with the style and forms

24 National Gazette, 19 January 1841: [2-3]. Excerpts from the review are reproduced in Upton, William Henry Fry, 45-7.

25 National Gazette, 19 January 1841: [3].

26 Upton, William Henry Fry, 47.

27 Songs, Duetts, Trios, Concerted Music, and Choruses of Anne Boleyn: A Grand Opera Seria, in Three Acts ([Philadelphia]: King \& Baird, 1844). 
of the primo ottocento, ${ }^{28}$ without which Leonora would have been a different work altogether.

\section{Leonora: Composition, Words and Music}

Joseph Fry's libretto for Leonora derives from Edward Bulwer-Lytton's popular play The Lady of Lyons. Not surprisingly, several changes intervened in the process of adapting the literary source for the operatic stage. As William Henry explained in his 'Prefatory Remarks' to the printed piano-vocal score published by E. Ferrett \& Co. in 1845 :

Certain modifications have been made in the scenes and characters for musical purposes: in the omission of some persons; in the increased prominence given to others; in the change of place, and of the time to a more distant and hence romantic era. $^{29}$

If the composer felt the need to address these changes, the poet did not. Instead, in an introductory 'note' dated 7 June 1845 and printed at the beginning of the libretto of Leonora, Joseph Fry stressed that the poetry was written to fulfil the needs of the composer, and with little observance of the conventions of English prosody:

The metres and stanzas, with scarcely a dozen exceptions, are eccentric, and are based upon no English model. If they sound properly when united with the melodies and recitatives to which they belong, the purpose of the writer is accomplished. To make verses in iambics, four or five to the line, is what anyone may do. But to frame a drama in rhyme, broken at every step into couplets or quatrains of dissimilar and unusual measures, is a task so peculiar as to claim the reader's indulgence, if executed with simple regard to sense and grammar. This is all the writer of these words professes to have done. ${ }^{30}$

The English versification of this libretto is indeed unconventional. The variety and flexibility of stanzaic patterns, and the wide use of irregular poetic metres are reminiscent of Joseph's own translation of Norma. ${ }^{31}$ The same can be said of the macrostructure of the libretto, which reflects the conventions of early nineteenth-century Italian practice. Each act consists of several tableaux, and each tableau is structured to become a musical number of the opera - an aria, a duet, or an ensemble. Accordingly, William Henry Fry divided his score into 21 numbers. The overall structure of Leonora is outlined in Table 1.

28 Primo ottocento is often used to refer to the Italian early nineteenth century.

29 William Henry Fry, 'Prefatory Remarks', in Leonora: A Lyrical Drama in Three Acts, Vocal Score (New York and Philadelphia: E. Ferrett \& Co., 1846): iv.

30 Joseph R. Fry, Leonora: A Lyrical Drama, in Three Acts: Words by J.R. Fry; music by W.H. Fry (Philadelphia: King and Baird, 1845): [2].

31 It is remarkable to see how easily many passages of Joseph Fry's idiosyncratic poetry were transformed into regular Italian metres for an Italian-language production in New York in 1858. A copy of the 1846 piano-vocal score in the Harvard University music library, presumably used for that production, shows numerous portions of the printed text underlaid with passages of Italian poetry. 
Table 1 Structure of Leonora

\begin{tabular}{|c|c|c|c|c|}
\hline Number & Title in A & Title in PV & $\begin{array}{l}\text { Location } \\
\text { in A (page } \\
\text { number) }\end{array}$ & $\begin{array}{l}\text { Location } \\
\text { in PV (page } \\
\text { number) }\end{array}$ \\
\hline & [No title given] & Overture & 3 & 1 \\
\hline \multicolumn{5}{|l|}{ Act I } \\
\hline 1 & $\begin{array}{l}\text { Introduction } \\
\text { Aria with Chorus } \\
\text { [Montalvo] }\end{array}$ & $\begin{array}{l}\text { Introduction } \\
\text { [Introduction, } \\
\text { cont.] }\end{array}$ & $\begin{array}{l}29 \\
54\end{array}$ & 17 \\
\hline 2 & Aria of Julio & Scene and Air & 101 & 60 \\
\hline 3 & Duetto [Julio, Montalvo] & Duet & 121 & 84 \\
\hline 4 & Chorus and Ballet & Chorus & 145 & 106 \\
\hline 5 & Scena ed Aria [Leonora] & $\begin{array}{l}\text { Scene and } \\
\text { Cavatina }\end{array}$ & 161 & \\
\hline 6 & Recitativo e Coro & $\begin{array}{l}\text { Recitative } \\
\text { and Chorus }\end{array}$ & 187 & 138 \\
\hline 7 & $\begin{array}{l}\text { Quartet } \\
\text { [Leonora, Julio, } \\
\text { Montalvo, Valdor] }\end{array}$ & Quartet & 199 & 158 \\
\hline 8 & Aria: Julio & Aria & 209 & 160 \\
\hline 9 & Finale to Act I & Finale to Act I & 220 & 166 \\
\hline \multicolumn{5}{|l|}{ Act II } \\
\hline 10 & $\begin{array}{l}\text { Introduction. Chorus } \\
\text { of Bridesmaids }\end{array}$ & $\begin{array}{l}\text { Chorus of } \\
\text { Bridesmaids }\end{array}$ & 253 & 197 \\
\hline 11 & $\begin{array}{l}\text { Recitative and Duet } \\
\text { [Leonora, Julio] }\end{array}$ & $\begin{array}{l}\text { Recitative } \\
\text { and Duet }\end{array}$ & 281 & 213 \\
\hline 12 & Aria [Montalvo] & Aria & 329 & 243 \\
\hline 13 & Invocation & $\begin{array}{l}\text { Invocation, } \\
\text { Quartet and } \\
\text { Chorus }\end{array}$ & 360 & 259 \\
\hline 14 & $\begin{array}{l}\text { Introduction, } \\
\text { Recitative and Aria } \\
\text { [Mariana] }\end{array}$ & $\begin{array}{l}\text { Introduction } \\
\text { and Romance }\end{array}$ & 387 & 278 \\
\hline 15 & $\begin{array}{l}\text { Recitative and Duet } \\
\text { [Leonora, Julio] }\end{array}$ & $\begin{array}{l}\text { Recitative } \\
\text { and Duet }\end{array}$ & 395 & 282 \\
\hline 16 & Finale to Act ${ }^{\mathrm{d}}$ & $\begin{array}{l}\text { Finale to } \\
\text { Act II }\end{array}$ & 470 & 321 \\
\hline \multicolumn{5}{|l|}{ Act III } \\
\hline 17 & $\begin{array}{l}\text { Descriptive Interlude } \\
\text { [Julio] }\end{array}$ & $\begin{array}{l}\text { Interlude. } \\
\text { Recitative } \\
\text { and Air }\end{array}$ & 524 & 379 \\
\hline 18 & $\begin{array}{l}\text { [No title given] } \\
\text { [Julio] }\end{array}$ & Air & 548 & 388 \\
\hline
\end{tabular}




\begin{tabular}{|c|c|c|c|c|}
\hline Number & Title in $A$ & Title in PV & $\begin{array}{l}\text { Location } \\
\text { in A (page } \\
\text { number) }\end{array}$ & $\begin{array}{c}\text { Location } \\
\text { in PV (page } \\
\text { number) }\end{array}$ \\
\hline 19 & $\begin{array}{l}\text { Recitative and Trio } \\
\text { [Leonora, Montalvo, } \\
\text { Valdor] }\end{array}$ & $\begin{array}{l}\text { Recitative } \\
\text { and Trio }\end{array}$ & 561 & 393 \\
\hline 20 & Chorus & Chorus & 575 & 398 \\
\hline 21 & Finale to the Opera & $\begin{array}{l}\text { Finale to } \\
\text { Act Third }\end{array}$ & 588 & 405 \\
\hline
\end{tabular}

A = William Henry Fry, Leonora, autograph score (US-PHhs).

PV = William Henry Fry, Leonora: A Lyrical Drama in Three Acts, vocal score (New York and Philadelphia: E. Ferrett \& Co., 1846).

The composer's fascination with the Italian tradition is immediately evident in the titles of several numbers, which are in the Italian language. More important, most numbers divide into several movements, usually following a multipartite pattern - the so-called solita forma that has occupied so many scholars of Italian opera during the past 30 years, which essentially consists of two lyrical sections (a slow cantabile and a fast cabaletta or stretta), usually preceded by a recitative or scena and connected by a middle movement (tempo di mezzo).$^{32}$ In duets and ensembles, the slow section is usually preceded by a fast opening movement (primo tempo). ${ }^{33}$

The poetry for the protagonist's entrance aria in Act I (No. 5) exemplifies how most numbers in Leonora were designed with this basic structure in mind (see page 16). The passage divides neatly into four parts: an initial section in free verse leads to the aria 'My ev'ry thought'. The intervention of the chorus creates the opportunity for a brief tempo di mezzo, leading to another lyrical section (marked 'Air' in the printed libretto), this time in trochaic tetrameters. The participation of the chorus and Valdor in Leonora's 'Scena ed Aria' is also in line with contemporary Italian opera conventions. The chorus and/or other characters would frequently take part in an aria, thus introducing a dialogic element into the scene and allowing for dramatic progression. Fry certainly knew examples of this, such as Norma's 'Casta Diva' and Amina's cavatina 'Come per me sereno' in Act I of Bellini's La sonnambula, in which structures and forces analogous to those of Leonora's cavatina are employed. His music for this number indeed follows the structure of the poetry as closely as one might expect, and corresponds precisely to the plan of the solita forma described above: an orchestral prelude (bars 1-14) introduces the scene ('Dear friends', bars 15-49); 'My ev'ry thought' is set as a cantabile (moderato, bars 54-90); the brief chorus 'Ah! no, fair Leonora'

32 A comprehensive bibliography on this subject would go well beyond the boundaries of this study. My terminology and descriptions reflect Martin Chusid, 'The Organization of Scenes with Arias: Verdi's Cavatinas and Romanzas', Atti del $I^{\circ}$ Congresso Internazionale di Studi Verdiani: Venezia, Fondazione Giorgio Cini, 31 luglio-2 agosto 1966 (Parma: Istituto di Studi Verdiani, 1969): 60; Robert Moreen, 'Integration of Text Forms and Musical Forms' (PhD diss., Princeton, 1975); Harold S. Powers, "“La solita forma” and "The Uses of Convention"', Acta Musicologica 59 (1987): 65-90.

33 Following an expression found in Abramo Basevi's Studio sulle opere di Giuseppe Verdi (Florence: Tipografia Tofani, 1859), Powers employs the term tempo d'attacco for the opening movement. However, composers of the primo ottocento consistently used primo tempo. 
serves as a tempo di mezzo (bars 91-112); and 'Now that smiles glad ev'ry hour' is set as a cabaletta (bars 113-227).

Leonora Dear friends, I greet you, rejoicing,

[scena]

In the presence of all who deign to honor

On this my happy birthnight, our festal halls.

Whate'er I witness fulfils the fondest promise

Of flatter'd fancy.

Valdor Thus may friends and fortune ever,

Dear Leonora, smile upon thee!

Leonora Ah! my too indulgent father, I owe to thee alone

Both friends and fortune. Thy generous affection

Hath made the world to me a paradise.

The happy memories of childhood,

The bright reflection of the present,

The sweet assurance of the future,

All make me grateful to heaven and thee!

Aria.

My ev'ry thought, my ev'ry word

[cantabile]

Hath grateful echo from all around me;

My heart, as free as soaring bird,

Exulteth proudly in liberty;-

Why should I ever this free heart surrender?

Why hope that love its homage may tender?

Chorus Ah! no, fair Leonora, can we believe thee? [tempo di

May not full many love thee, who ne'er would deceive thee. mezzo]

Leonora (aside) Mid the smiles that glad the hour,

Air. [cabaletta]

And with joy my bosom thrill;

While no clouds o'er life yet lower,

And new hopes are dawning still:

Ah! gentle fate, let naught allure me

With my freedom e'er to part,

Till affection true assure me

That purer bliss shall crown my heart!

Chorus Ah! who would not with virtue so rare

For aye be content his lot to share?

Such a strict correlation between textual and musical forms makes one wonder how the structure of Leonora was mediated between poet and composer. The extant primary sources provide no details on when the libretto was conceived and written. Nonetheless, since Joseph and William Henry were siblings and lived in the same city, we can safely assume that they worked in close proximity during the gestation of Leonora. Even though it is plausible that a draft (or at least a detailed synopsis) of the libretto was written prior to the musical setting, a number of textual details suggest that the final version of the lyrics was devised to fit the music during or following its composition. Several passages of poetry appear to have been devised or modified to fit William Henry's melodic lines, resulting in frequent metrical eccentricities, about which, as we have seen, Joseph felt the need to warn the reader. ${ }^{34}$ Furthermore, the layout of numerous

34 Fry, 'Prefatory Remarks', iv. 
sections within the autograph score strongly suggests that Fry wrote many of his melodies before the text was available. Much of the poetry was entered into the score at a late stage of composition, in pencil or in a different ink from that used for the vocal lines. In many places, the composer did not allow himself sufficient space to enter the words neatly and clearly, and was forced to write them in an unusually clumsy and close fashion.

Most numbers of Leonora share this structural relationship between text and music. This is immediately obvious in the arias, whose structures are similar to that of No. 5; Montalvo's aria in Act II (No. 12), which lacks an introductory scene, otherwise fits the solita forma pattern perfectly. Leonora's final aria (No. 21) is in four sections. Julio's aria at the beginning of Act III also has a multi-movement structure derivative of Italian conventions, although it appears in the score as two different numbers. No. 17 (entitled 'Descriptive Interlude' in the autograph score) includes an orchestral prelude, a recitative, a slow movement and a middle movement, and No. 18 is a cabaletta dramatically and tonally related to the preceding scene.

The composition of Julio's first aria (No. 2) shows how Fry experimented with different approaches to the solita forma. The original version of this piece follows a more complex pattern than the conventional number structure described above:

Section 1: Orchestral prelude (bars 1-10) and scene 'The sun declineth slowly' (bars 11-59)

Section 2: Andante 'Oh fortune!' (bars 60-134)

Section 3: Middle section:

(a) Dialogue 'My brother! Julio!' (bars 135-76)

(b) Andante 'Grant me one only hour' (Julio) (bars 177-207)

(c) Dialogue 'Dear Julio' (bars 208-42)

Section 4: Cabaletta allegro non tanto 'Ah! canst thou bid me smother' (bars 243-346)

The most striking formal feature of this number is the presence of a second slow lyrical episode (the andante 'Grant me one only hour'), which interrupts the otherwise kinetic middle section. This is not a common procedure in contemporary Italian entrance arias. Rather, the organization of this number may have been influenced by the final scene of Donizetti's Anna Bolena, whose cantabile and cabaletta are separated by a long middle episode that includes an additional lyrical section ('Cielo a' miei lunghi spasimi'). ${ }^{35} \mathrm{Julio}$ 's aria appeared in this form in the piano-vocal score published by Ferrett. However, 'Grant me one only hour' was subsequently crossed out in the autograph score and its text does not appear in the printed libretto. The piece, together with several other portions of the opera, was probably cut before the 1846 run of performances, perhaps to ease the demands of this unusually long scene on tenor John J. Frazer, who sang the role of Julio. Without the cantabile, the middle section became a conventional kinetic episode (a tempo di mezzo proper), providing a straightforward musical and dramatic link from the slow movement to the cabaletta.

35 This type of structure is encountered in several of Rossini's serious operas, and in his autograph scores the composer himself described them with the term 'gran scena'. None of those operas were performed in Philadelphia, however, and it seems more likely that the protagonist's final scene in Anna Bolena served as the direct model for Julio's aria. 
Italian models also inform the organization of duets and ensembles. For example, the introduction (No. 1), in line with the conventions of Italian opera introduzioni, consists of a choral section followed by a two-movement aria for one of the principal characters (Montalvo). ${ }^{36}$ The duet for Leonora and Julio in Act II (No. 15) is an extended number consisting of an elaborate scena, a primo tempo, a slow lyrical section with singing in paired thirds and sixths, and a cabaletta with contrasting themes for the two characters. And the confrontational duet for Julio and Montalvo in Act I (No. 3), tellingly titled 'Duetto' in the autograph score, lacks the conventional slow movement characterized by a 2 singing, but otherwise has a similar structure.

Compared to these and other numbers, Mariana's aria in Act II (No. 14) has a much simpler structure. It is a short number in a single section - a simple strophic song consisting of two stanzas of text set to the same music and introduced by an orchestral prelude with a solo for the oboe. This type of number may derive either from the Italian romanza, a simple number consisting of a prelude and/or a scena followed by a slow movement (often in strophic form), ${ }^{37}$ or from the French romance and couplets, common in opera-comique and certainly known to Fry through performances of French works in Philadelphia. ${ }^{38}$ Not surprisingly, in the printed piano-vocal score this number came to be entitled 'romance'.

Furthermore, ternary forms such as the one employed for Julio's single-movement aria towards the end of Act I (No. 8), or those found in the slow movements of several solo numbers, also suggest that there are important French elements in Leonora, since the use of ternary patterns does not belong in the contemporary Italian tradition. Lyrical movements of Italian arias are normally in a 16-measure pattern consisting of four phrases of four measures each (mostly arranged as AABA or AABC), and usually followed by a coda. ${ }^{39}$ Whereas Fry's cabalettas follow this pattern without exception, the slow movements of his solo numbers typically present ampler ABA forms - the A section following phrase structures similar to those outlined above. Leonora's cantabile 'My ev'ry thought' in No. 5, with its A section in A, major followed by section $B$ in the key of the dominant and by a full reprise of $A$, is a case in point. The frequent use of ternary forms is a clear indication that, as observed by some of the early commentators cited at the beginning, in the composition of Leonora Fry also kept a close eye on French opera, as well as, perhaps, contemporary English works such as Michael William Balfe's The Bohemian Girl (1843).

But the Italian influence predominates, and is visible not only in Fry's extensive - albeit not exclusive - use of the solita forma, but also in other stylistic aspects of Leonora. In fact, several reviews and comments cited at the beginning of this article

36 An insightful discussion of this type of number is David Rosen, 'How Verdi's Operas Begin: An Introduction to the Introduzioni', Verdi Newsletter 16 (1988): 3-18.

37 See Chusid, 'The Organization of Scenes with Arias', 62. Fry might well have known the famous romanza for Giulietta in Act I of Bellini's I Capuleti e i Montecchi (1830); he certainly knew Smeton's 'Deh! non voler costringere' in Act I of Donizetti's Anna Bolena. Both pieces are in strophic form.

38 One instance is Férdinand Herold's Zampa (1831), given in English translation at the Chestnut Street Theatre in 1841. Fry's mind may have resonated with Alphonse's couplets 'Mes bons amis' or with Camille's popular ' $\mathrm{D}$ ' une haute naissance'.

39 Scholars have adopted the term 'lyric form' to refer to this pattern. See, for example, Joseph Kerman, 'Lyric Form and Flexibility in Simon Boccanegra', Studi verdiani 1 (1982): 47-62; Scott Balthazar, 'Rossini and the Development of the Mid-Century Lyric Form', Journal of the American Musicological Society 41 (1988): 102-25; and Steven Huebner, 'Lyric Form in Ottocento Opera', Journal of the Royal Musical Association 117 (1992): 123-47. 
suggest that the melodic idiom is the most characteristically Italian trait of the opera. Indeed, most of the tunes of Leonora recall the style of Fry's Italian contemporaries. Every lyrical movement in the opera begins with a statement of the principal melody in which the rhythm and the character of the piece are immediately defined. Often, as customary in the works of Bellini, Donizetti and the young Verdi, the melody is introduced by the orchestra before it is taken up by the singers.

Although literal quotations of other composers are not found in Leonora, several melodies recall Bellinian models: Leonora's cabaletta in Act I, for example, is clearly indebted to Amina's final cabaletta in La sonnambula (see Exx. 1a and 1b). Aside from the obvious affinities between the melodic lines, the relationship between the two pieces is evident already in the orchestral introductions, both of which end with a characteristic loud dominant chord and a fermata.

\section{Ex. 1(a) Leonora, Act I}
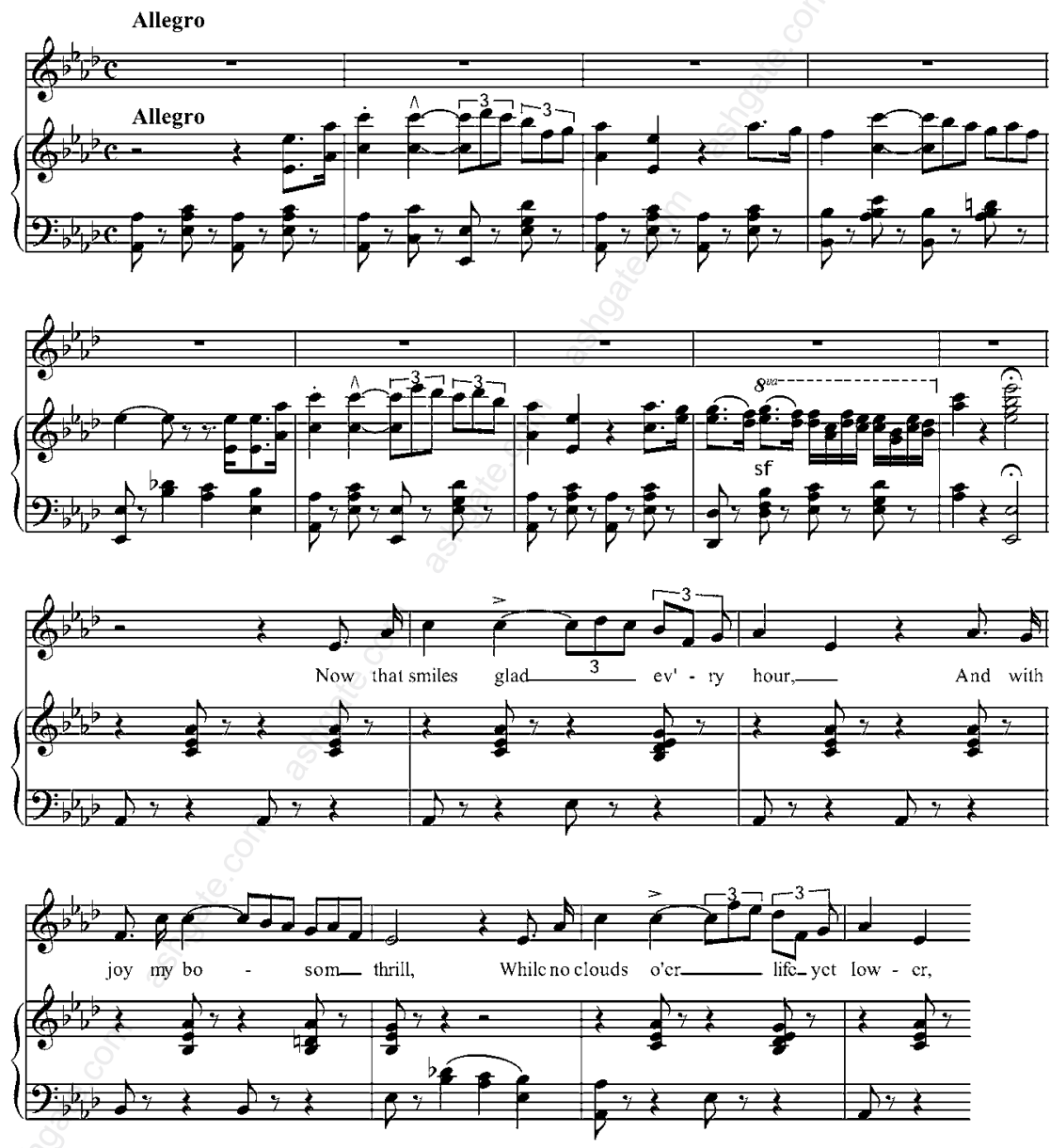
Ex. 1(b) Bellini, La sonnambula, Act II
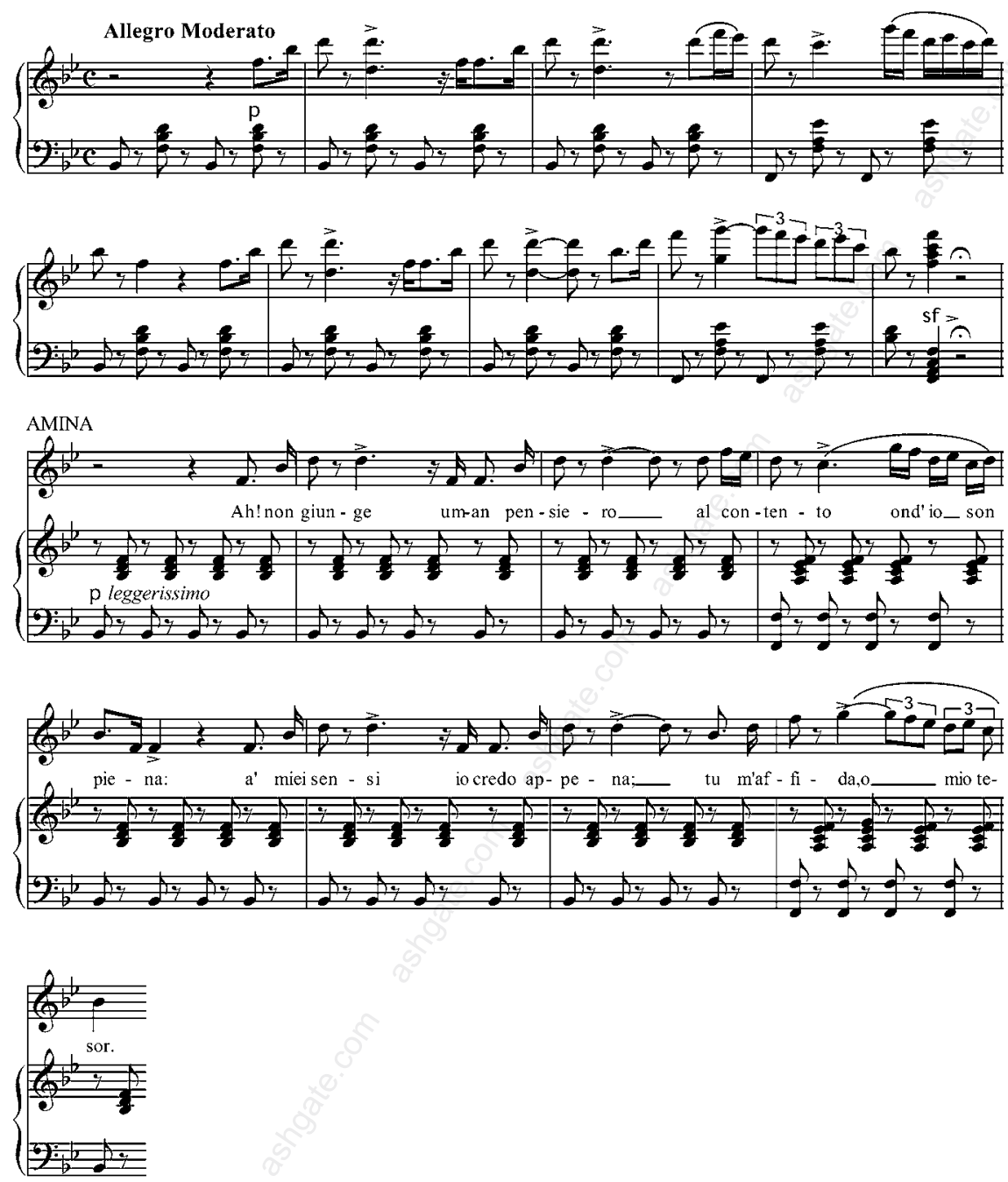

Most vocal lines involve a rich use of melodic ornamentation. Ornamental figures of three or four notes are often employed in the resolution of dissonances and in phrase endings on descending intervals, with frequent and clear resemblances to melodic details in Bellini's operas. Exx. 2a and 2b show a passage from Julio's aria in Act I of Leonora and a similar passage from Amina's cavatina in La sonnambula. Exx. 3a and 3b show a flourish in Leonora's cabaletta in Act III, which resembles a figure from Norma's cabaletta in Act I.

The singers who created Leonora, especially Arthur Seguin (Montalvo) and his wife Ann Childe (Leonora), had an extensive background as interpreters of Italian opera, first in London and later in the United States. Not surprisingly, the vocal writing of Leonora requires considerable technical skills, especially (but not exclusively) for the role of the female protagonist. In line with contemporary 
Ex. 2(a) Leonora, Act I

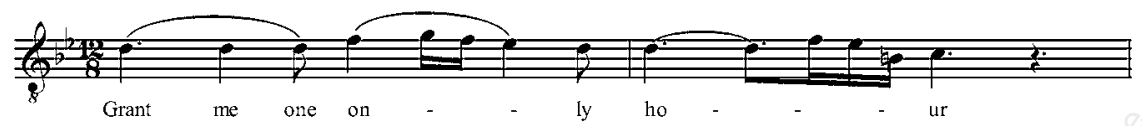

Ex. 2(b) Bellini, La sonnambula, Act I

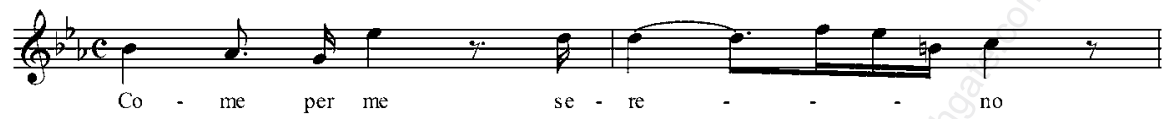

Ex. 3(a) Fry, Leonora, Act III

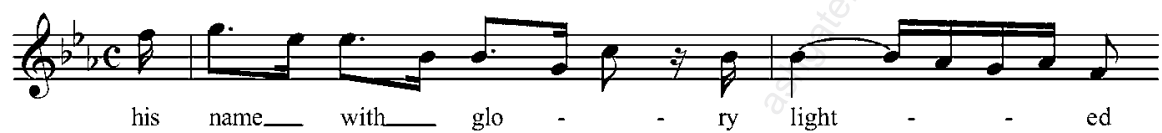

Ex. 3(b) Bellini, Norma, Act I

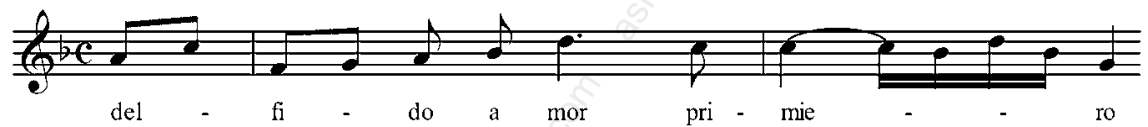

Italian vocal style, the most virtuosic episodes are found in the cabalettas, which often include long vocalized passages. A passage of coloratura from Leonora's cabaletta in Act I is reproduced in Ex. 4. Cadenzas regularly occur at the end of slow lyrical sections, as in Italian arias. In line with post-Rossinian practice, those for the leading female character are usually particularly elaborate, but there are opportunities for virtuosic display in other parts as well, and particularly in the part of Montalvo (see Ex. 5).

The accompaniments are largely similar to those encountered in Bellini and Donizetti. In lyrical movements there is an overwhelming predominance of arpeggiated triplets and repeated chords. The similarity of the accompaniments of 'Ciel pietoso' from Bellini's La straniera and of Julio's cantabile 'Grant me one only hour' in No. 2 of Leonora is more telling than any further description (see Exx. $6 \mathrm{a}$ and $6 \mathrm{~b}) .{ }^{40}$ In his scenas and middle movements, the orchestra tends to be more active, and Fry reveals remarkable skill in the employment of parlante, a technique based primarily on syllabic singing of limited melodic relevance over repeated

40 Whilst it is most likely that Fry had Italian models in mind when he devised his accompaniments, the formulaic nature of these and other accompanimental figures is hardly an exclusive feature of contemporary Italian opera, but is shared by a number of styles and repertoires. 
rhythmic and melodic cells in the orchestral accompaniment. ${ }^{41}$ Ex. 7, taken from the middle movement of Julio's first aria in Act I, illustrates the use of this device.

\section{Ex. 4 Leonora, Act I}

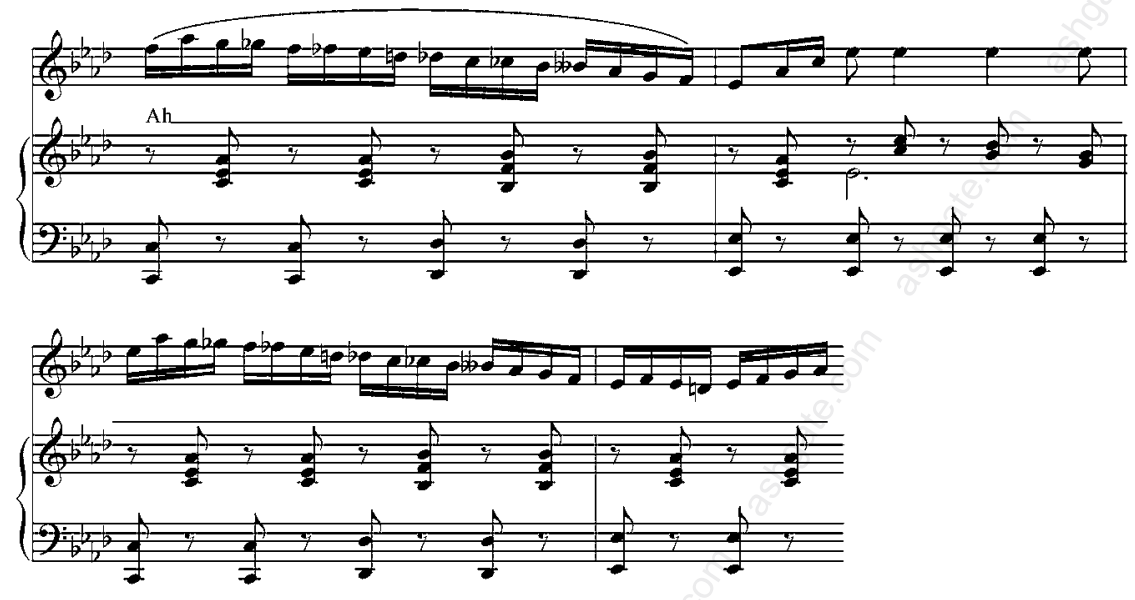

Ex. 5 Leonora, Act II
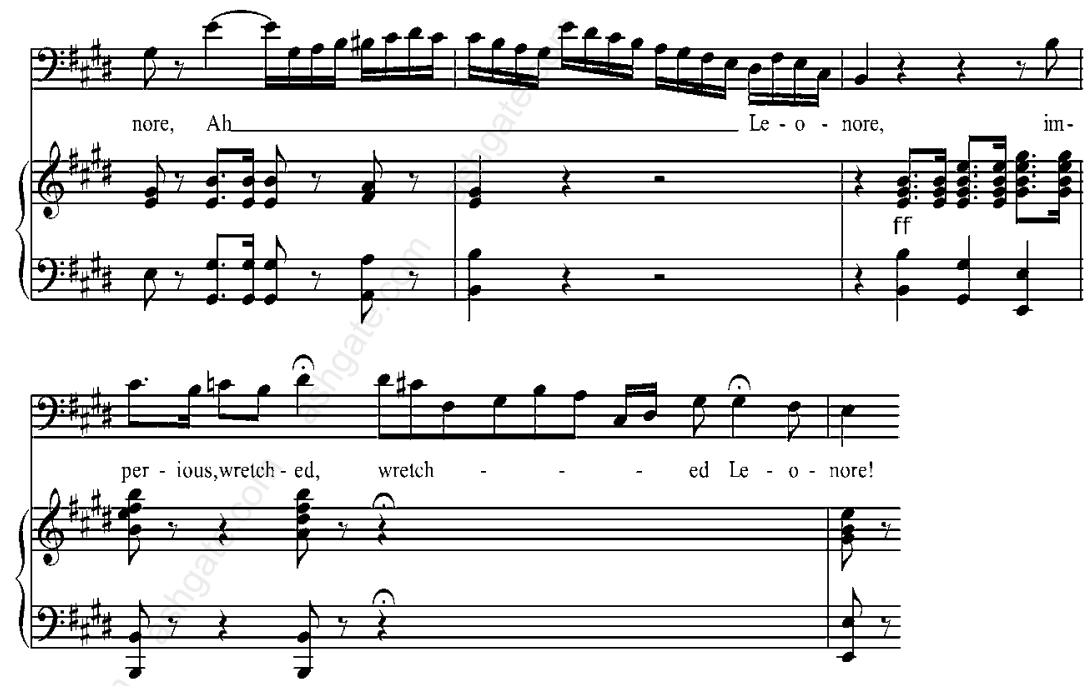

41 The term parlante was used extensively by nineteenth-century Italian composers and critics. A detailed description of this technique is found in Abramo Basevi, Studio sulle opere di Giuseppe Verdi (Florence: Tipografia Tofani, 1859): 30-32. 
Ex. 6(a) Leonora, Act I
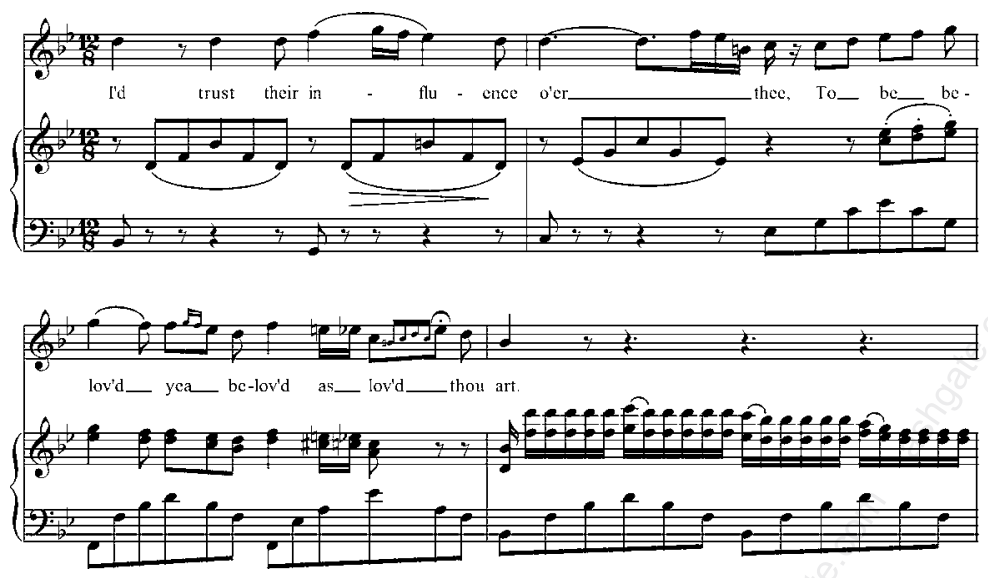

Ex. 6(b) Bellini, La straniera, Act II
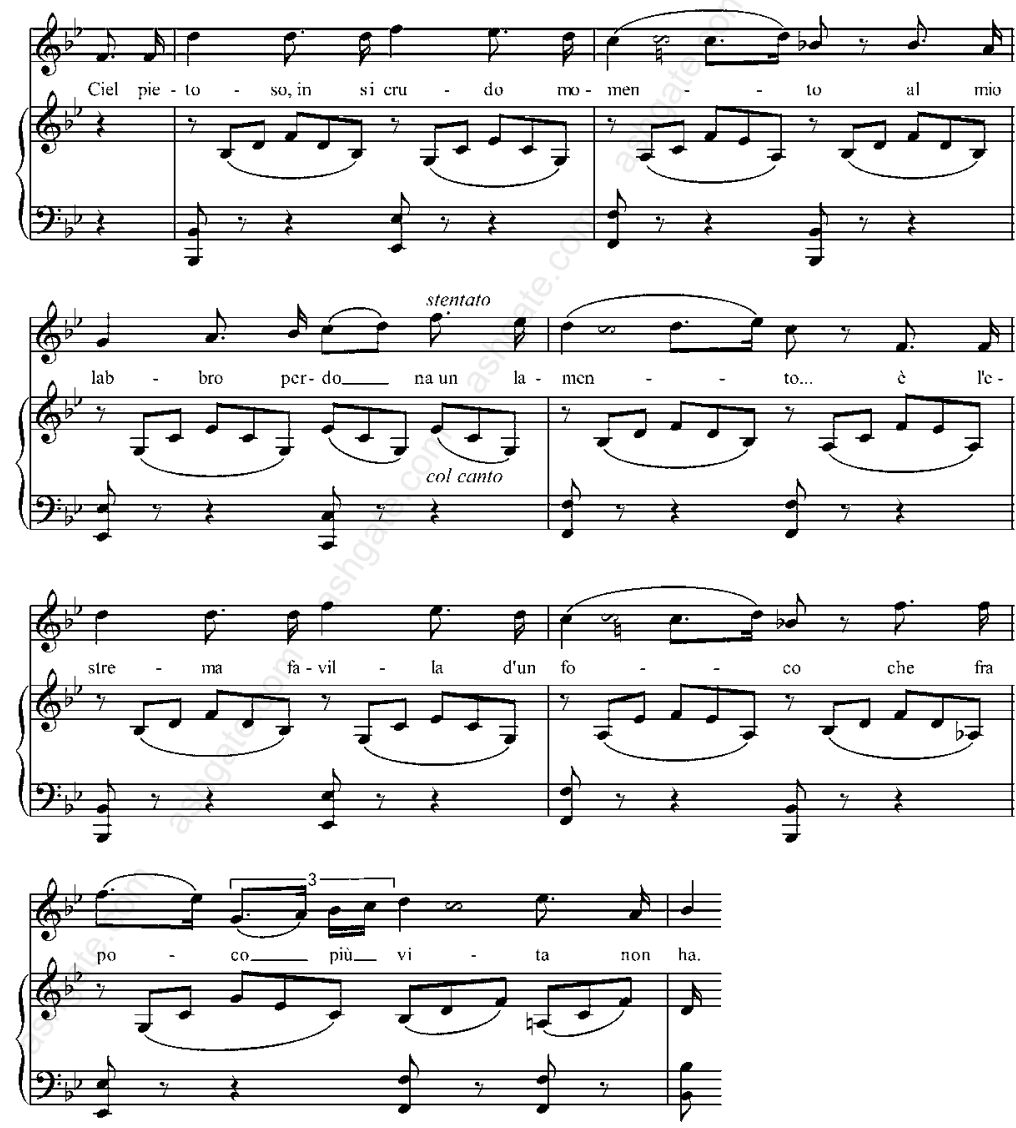


\section{Ex. 7 Leonora, Act I}
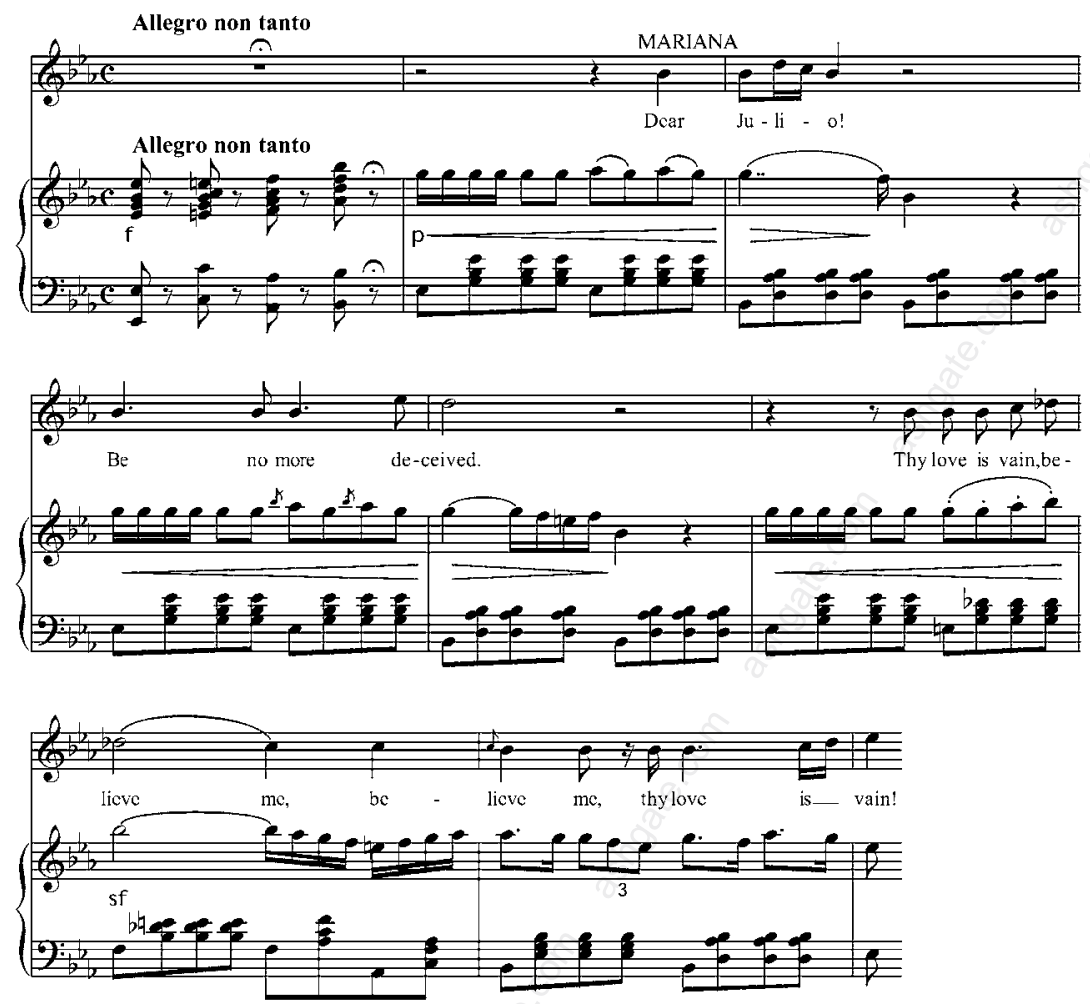

\section{Conclusion}

The libretto and the music of Leonora show a profound familiarity with the styles of contemporary Italian opera - a familiarity that involved terminology, poetic and musical forms, melodic style, ornamentation and accompaniment techniques. Fry's aim was not to create a 'national' style of American opera. As he stated at the beginning of his 'Prefatory Remarks' to the vocal score of Leonora, ' $[\mathrm{t}]$ his lyrical drama was produced on the stage with a view of presenting to the American public, a grand opera [that is, an opera with no spoken dialogue and 'recitative accompanied by the orchestra'], originally adapted to English words'. ${ }^{42}$ The key word here is 'original', which refers not to the style of the music, but to the idea of setting new music to a new libretto (as opposed to a translation) written in the English language. That music reflected Fry's desire to follow in the footsteps of his Italian contemporaries, whom he called 'the masters of vocal music'. ${ }^{43}$ His awareness and declared admiration for those masters, rather than any nationalistic concern, were the determinant factors that shaped Leonora.

42 William Henry Fry, 'Prefatory Remarks', iii.

43 Ibid., iv. 
The music of this opera certainly does not sound American. But the one-man enterprise that prepared the terrain for its creation could only have taken place in the United States. It is because of William Henry Fry that the confluence of the Schuylkill and the Delaware rivers so rapidly became a safe harbour for the works of the primo ottocento masters. The direct line proceeding from William Henry Fry's early predilection for Italian opera to his activities on its behalf in Philadelphia (first as critic and then as promoter of the groundbreaking production of Norma), leading finally to his own Leonora at a time when the audience would receive it not as an absolute novelty, but as 'an old acquaintance in a new coat', is far more than a fascinating episode in the history of opera in the mid-nineteenth-century United States. It is first and foremost an extraordinarily successful cultural manoeuvre, with far-reaching ramifications for the taste of the public and for the establishment of a performing repertory in the United States. 
